\title{
INTERCOMPANY NETWORKS: THE PROBLEMS OF DETERMINING THE VALUE ADDED IN INDUSTRIAL MARKETS
}

\author{
Prof., DSc. Zoya A. Vasilyeva \\ Assistant professor Tatiana P. Likhachyova \\ Senior lecturer Anna V. Moskvina \\ Assistant Tatiana A. Burmenko \\ Assistant Naira A. Bagdasaryan
}

\author{
Siberian Federal University, Russia
}

\begin{abstract}
This article discusses the methodological issues of determining value added in the framework of intercompany networks - industrial clusters, which is an effective tool for analyzing and decision making. A sequence of stages of the formation of value chains (VCC) is proposed, their features and mechanisms for optimizing the interaction and coordination of actions of participants according to the criterion of gross value added (GVA) are highlighted. An approach to the definition of value added in the framework of global value chains (GVC) is given. Emphasis is placed on the performance indicators of the VCC and respect for the interests of stakeholders.
\end{abstract}

Keywords: network forms of business organization, value creation networks, the formation of value added.

\section{INTRODUCTION}

The increased competition in foreign and domestic markets makes it necessary to seek effective management tools that will make it possible to more clearly identify strategic development priorities in the conditions of external environmental instability. In addition, the modern economy is on the way of complicating forms of business organization and ways to coordinate the activities of economic entities in the emerging global trends, which, in turn, requires new modern analytical tools for decision-making. One of these tools, in our opinion, is the value chain (VC), which allows to highlight the problems of inter-company interaction within the network, positioning of all of its participants, assess the potential opportunities and threats of each and the network as a whole and propose solutions to improve the efficiency of return. The intensification of integration processes in international trade and the introduction of the concept of "global value chains" (GVC) can be noted.

The task of forming the VC was based on the need to evaluate both already manufactured products and those planned for release by including new participants and establishing its most preferable options in terms of:

1. expanding the range of high-tech products;

2. strengthening the competitive position in the market as a result of the interaction of all network participants and the increase in value added.

The study is based both on theoretical generalizations made both on the basis of the works of classics and scholars, and on practical examples from various sectors of the economy. 


\section{Theoretical aspects of the research}

An intercompany network is a set of interconnections that are based on the sharing of specific resources. It involves the development of a generalized strategy for adapting participants to changes in the external environment [1]. The advantage of cooperation, as a rule, is conditioned by the possibility of solving common problems: the functioning of supply systems, sales, protection of interests, etc.

Since intercompany networks are stable, one can imagine their architecture, where there are centers and ways of coordination and distribution of power, value extraction. At the same time, the dominant participants create and maintain rules for interaction in such networks [2].

The advantages of the network form include:

- high degree of independence of participants;

- he ability to change the network configuration when changing consumer needs or when rebuilding technological chains.

At the same time, within the framework of the studied issue, two such important aspects should be noted, such as the asymmetry of information about the processes occurring within the boundaries of the participating companies and the competition between them regarding the distribution of performance results [3].

Intercompany networks have their own typology [4, 5], among which clusters are distinguished as a form that has received the most distribution and support in the Ministry of Industry and Trade of the Russian Federation.

There is a separate class of network structures that emerges with the development of regional, interregional and interstate economic relations. Such networks are characterized by the following three features:

1. presence of stable cooperation relations between the participants;

2. established interaction architecture;

3. synergistic effect - collective efficiency (value).

The concept of "value chain" was introduced by M. Porter [3] to study the individual components of the economic activity of enterprises, aimed at identifying their competitive advantages. M. Porter's approach was developed in the works of R. M. Grant [6], D. Schank and V. Govindarajan [7], A. Thompson and A. Strickland [8], R. Kaplinsky [9] already in the form of a value creation chain (VCC). A. Brandenburger and B. Neilbuff proposed to expand the interpretation of the VCC as a mechanism that increases the value of products and allows them to be distributed among all network participants [10].

Among Russian scientists, to the problems of formation of the VCC in the national and interfunctional aspects were given attention in the works of T. Meshkova, E.Ya. Moiseicheva [11], P.S. Andreeva, [12], and others. Research of T.V. Andreeva [13], S.E. Soldatova and K.Yu. Volozhenko [14] has applied nature and proposed approaches to identify participants and build structural and logical design stages of the VCC.

As for the GVC, their modern theory is presented in the most structured form in the works of R. Kaplinsky and G. Jereffi, they focus on the controlled and dynamic nature of the GVC, and the types of control offered by them within the GVC are the analytical framework on which assumptions are made. In practice, different types of management complement each other and can change as soon as the links in the chain and the main sources of rent are changed. It should be noted that today GVC are becoming not just an analytical structure, but are used as a tool for international economic regulation.

The analysis of the considered problem from the point of view of theoretical and applied 
aspects of its solution allows to speak about the absence of a systemic view on the formation of the VCC within the network of industrial structure with the access to different levels of management (industrial, regional, interregional). In this regard, it seems relevant to consider methodically the formation of value added and the VCC for the industrial cluster "Technological Valley" and the assessment of its significance for all stakeholders.

\section{Methodical aspects of the research}

The process of forming the VCC came from the need to address the following priority issues:

- information database on the participants of the intercompany network;

- uniformity in the understanding of "value added" and its structuring by levels of management;

- taking into account the interests of "stakeholders".

Organization of the cluster structure provides information openness of all participants.

International aspects of value added are determined on the basis of the choice of a country as a potential partner and the terms of contractual relations with foreign contractors.

International organizations - UNCTAD, OECD, WTO are involved in the assessment of value added. In 2013, the OECD-WTO database was opened, which characterizes the participation of 58 countries of the world in value-added trade, which account for $95 \%$ of the global GDP [15].

Gross value added (GVA) is calculated as gross value created (GVC), excluding the amount of funds consumed (1):

Gross value created (GVC) includes (2):

$$
\mathrm{GVA}=\mathrm{GVC}-\mathrm{CF}
$$

where:

$$
\mathrm{GVC}=\mathrm{CF}+\mathrm{WF}+\mathrm{ASN}+\mathrm{DA}+\mathrm{VATp}-\mathrm{VATd}+\mathrm{T}+\mathrm{Ps}
$$

$\mathrm{CF}$ - consumed funds that include material costs (MC), change in balances of work in progress, deferred expenses, reserves for forthcoming expenses and other expenses (CB);

WF - wage-fund;

ASN - allocations to social needs;

DA - depreciation amount;

VATp - amount of VAT payable;

VATd - amount of VAT deductible;

$\mathrm{T}$ - tax payments;

Ps - profit from sales of products, works, services (from sales).

On the basis of GVC a net value added can be determined (NVA), which is the newly created value in the form of incomes of employees and the enterprise itself (3). NVA differs from GVC by the depreciation index.

$$
\mathrm{NVA}=\mathrm{GVC}-\mathrm{DA}
$$

Figure 1 shows the element structure of the VA, which can be used for further analytical purposes.

GVA allows to identify partners of an intercompany network and choose their most optimal configuration based on the balance of interests of all of the stakeholders (Table 1).

For global value chains (GVC), in case when an intercompany network enters the 
international market, determines the indicator of the volume of gross value added in exports of national origin for a particular type of economic activity (4).

$$
\text { GVAe }=\text { GVAd }+ \text { ICD }+ \text { RI }
$$

where:

GVAe - gross value added in exports (total);

GVAd - gross value added in exports (direct);

ICD - intermediate consumption of domestic resources included in exports;

$\mathrm{RI}$ - re-imported value added in exports.

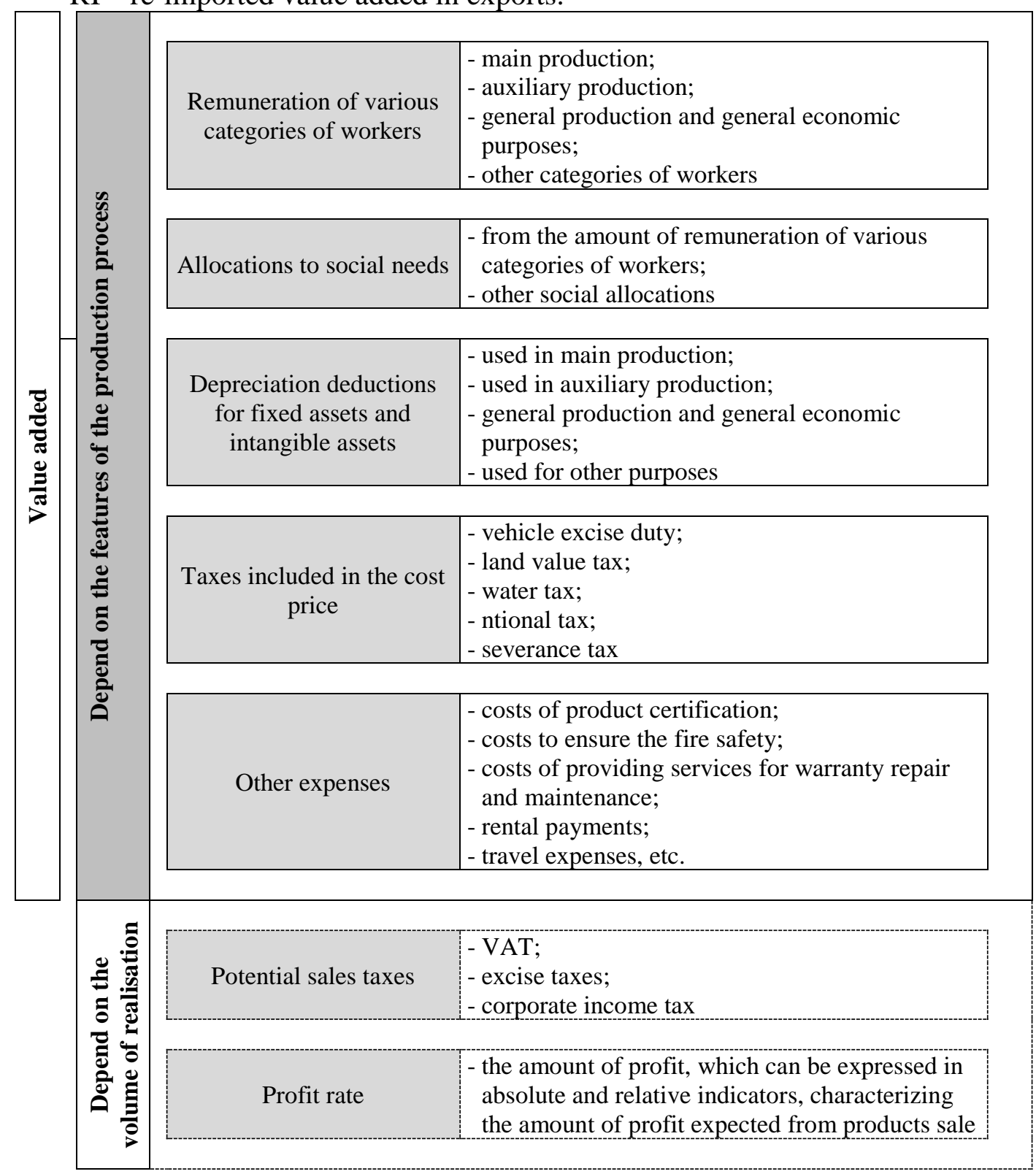

Figure 1 - The elemental structure of the value added of the company

Table 1 - Identification of results by variants of intercompany interactions

\begin{tabular}{|c|c|c|c|c|}
\hline \multirow{2}{*}{ Indicators } & \multicolumn{3}{|c|}{ Options of intercompany chains } \\
\cline { 2 - 4 } & 1 & 2 & $\ldots$ & $N$ \\
\hline Gross value created (GVC) & & & & \\
\hline Consumed funds (CF) & & & & \\
\hline
\end{tabular}




\begin{tabular}{|c|l|l|l|l|}
\hline Gross value added (GVA) & & & & \\
\hline Depreciation (D) & & & & \\
\hline Payments to the budget (PB) & & & & \\
\hline Net value added (NVA) & & & & \\
\hline Salary (S) & & & & \\
\hline Profit (P) & & & & \\
\hline
\end{tabular}

Compiled by the authors

The database TiVA (Trade in Value Added) is used to calculate the indicator, which allows to combine bilateral trade flows.

«Gross value added» (GVA) indicator depends on the performance of the network results and performs the basic source of the revenues of the regional budget, which is why both government and business are interested in its growth (Figure 2).

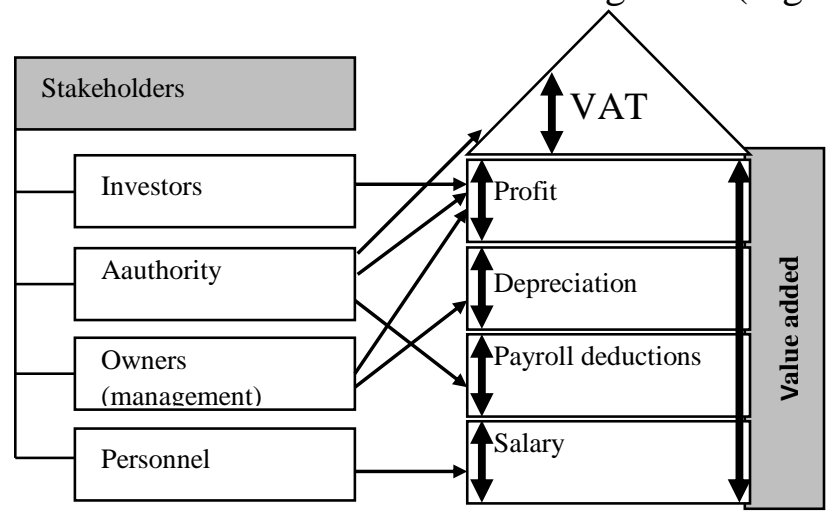

Figure 2 - The structure of value added and the distribution of its elements by the interested subjects of economic activity

Gross value added $\left(\mathrm{GVA}_{\mathrm{i}}\right)$, created at the level of an economic entity as a network participant is transformed into a network gross value added $\left(\mathrm{GVA}_{\mathrm{c}}\right)$, and it, in turn, in the gross value added of the type of economic activity $\left(\mathrm{GVA}_{\text {tea }}\right)$ and the region as a whole (GVA of the Krasnoyarsk region) (Figure 3).

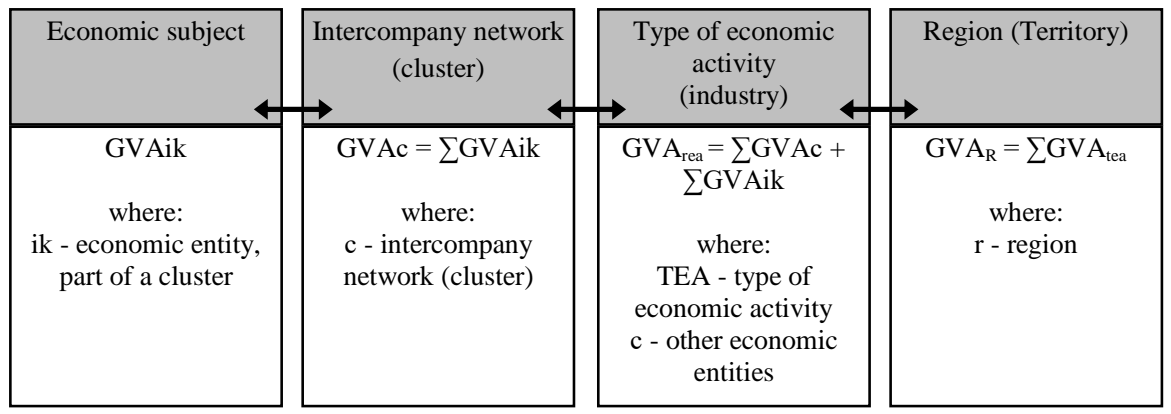

Figure 3 - Formation of gross value added by levels of economic management in the region

Thus, the indicator of GVA allows not only to assess the effectiveness of participation of economic entities in the network, but also to reach similar indicators in the sectoral and regional context, assessing the contribution of each level to the overall result of the region.

The following procedure for the formation of VCC at the level of an industrial cluster is proposed. 
Step 1. Determination of the scheme of industrial and technological cooperation of the cluster and identifying the types of activities (technological processes) involved in creating the value of the final product from the material flow (raw materials, materials, intermediate and finished products) to the key processes and activities (markets of goods, works, services). Determination of VCC composition of participants (business entities, networks, suppliers and contractors of network participants, potential partners).

Step 2. Identification of the control unit in the VCC - the type of activity, constituting the largest share of value added. Establishing the proportions of the distribution of value added between economic entities based on the average selling (retail) price per unit of product on the national, regional or foreign market where the finished product is sold or planned to be sold, determining the competitive advantages of network participants and their output performance not redistributed to other participants in the value chain.

Step 3. Strategic selection and verification of network activities and products manufactured in it for compliance with market conditions through assessment of transfer and market prices. Formation of a decision on the inclusion of the type of activity in the VCC or exit from it, including the transfer for the purposes of interregional or international cooperation outside the network.

Step 4. Identification of potential directions for improving VCC based on the analysis of the internal and external environment factors (SNW analysis, SWOT analysis) with a focus on Russian and international average industry values of indicators. Identification of opportunities for expanding VCC through vertical integration with suppliers of raw materials (back) or consumers of finished products (forward). Analysis of organizational perspectives and their alternatives, including the inclusion of the capabilities and competencies of foreign partners.

Step 5. Identification of alternative VCC options and evaluation of their performance. Systematization of activities and allocation of activities with the highest share of value added.

For each variant of VCC, value added quality indicators are defined, which are divided into:

- dynamics indicators;

- structure indicators;

- performance indicators.

Quality indicators of GVA are checked for their compliance with the interests of stakeholders. Table 2 provides a list of indicators of value added quality.

Step 6. Selection of the optimal VCC option based on a comparison of GVA quality indicators for alternative options (Table 2).

Table 2-GVA quality indicators within the network framework

\begin{tabular}{|c|c|}
\hline Indicators & Stakeholders \\
\hline \multicolumn{2}{|c|}{$\mathbf{I ~ G V A}$ structure indicators } \\
\hline 1.1 Wage share in GVA, \% & Personnel \\
\hline 1.2 Depreciation share in GVA, \% & Investors, business \\
\hline 1.3 Profit share in GVA, \% & Government, business \\
\hline \multicolumn{2}{|c|}{ 2 Performance Indicators } \\
\hline 1.4 The share of value added in exports, $\%$ \\
\hline \multicolumn{2}{|c|}{ 2.1 GVA per 1 rub. of GVC, rub./rub. } \\
\hline 2.2 GVA per 1 rub. of fixed investment, rub./rub. & Business \\
\hline 2.3 Wage per 1 rub. of GVA, rub./rub. & Personnel \\
\hline
\end{tabular}




\begin{tabular}{|c|c|}
\hline 2.4 Taxes (profit) per 1 rub. of GVA, rub./rub. & Government \\
\hline $\begin{array}{c}\text { 2.5 Direct GVA in exports per 1 rub. of total GVA in } \\
\text { exports, rub./rub. }\end{array}$ & Business \\
\hline \multicolumn{2}{|c|}{ 3 GVA dynamics indicators } \\
\hline 3.1 GVA growth rate, $\%$ & Business \\
\hline 3.2 NVA growth rate, $\%$ & Investors \\
\hline 3.3 Fixed investment growth rate, $\%$ & Investors \\
\hline 3.4 Tax payments growth rate, $\%$ & Government \\
\hline 3.5 GVA growth rate per 1 rub. of fixed investment, $\%$ & Business \\
\hline 3.6 GVA growth rate per 1 rub. of GVC, $\%$ & Business \\
\hline 3.7 Taxes (profit) growth rate per 1 rub. of GVA, $\%$ & Business, government \\
\hline $\begin{array}{c}\text { 3.8 Temп pocra (nрupocra) of direct GVA in exports } \\
\text { per 1 rub. of total GVA in exports, } \%\end{array}$ & Business, personnel \\
\hline
\end{tabular}

The most preferred network option is determined by the highest values of GVA quality indicators.

The stages of the formation of the VCC, based on the definition of the manager in the chain and the distribution of GVA among all network participants, including foreign ones, allow choosing the most effective network interaction option in terms of achieving a balance of interests of all stakeholders.

\section{Results and conclusion}

The authors have developed the scheme for the production and technological interconnection of participants in the industrial cluster, which formed the basis for preparing the database for GVA calculating and the VCC formation (picture 4).

VCC are defined by the type of activity: production of alumina, production of aluminum and alloys, production of intermediate and finished products, collection and processing of non-ferrous metal scrap.

Considered individual VCC configurations with a focus on domestic consumption as intermediate products and end users (Russian and international markets). The results confirmed the possibility of using the VCC to identify priority activities and product markets, bringing high GVA.

The potential of VCC, derived from the analytics, made it possible to consider options for strategic solutions of promising technologies and the release of new products that solve the problems of import substitution or export and change the inter-company network architecture (Figure 4). 


Obtainment of bauxites (from other regions of
the Russian Federation)

\begin{tabular}{|c|c|c|c|}
\hline $\begin{array}{l}\text { Obtainment of } \\
\text { aluminia }\end{array}$ & Obtainment of aluminia & & \\
\hline $\begin{array}{l}\text { Obtainment of } \\
\text { aluminia and its } \\
\text { alloys }\end{array}$ & $\begin{array}{l}\text { Primary aluminum and } \\
\text { its alloys }\end{array}$ & $\begin{array}{l}\text { Collection and } \\
\text { processing of non- } \\
\text { ferrous scrap }\end{array}$ & Off-cluster consumption \\
\hline $\begin{array}{l}\text { Obtainment of } \\
\text { aluminum products }\end{array}$ & $\begin{array}{l}\text { Products: } \\
\text { - } \quad \text { Car wheel disks } \\
\text { - } \quad \text { Aluminum pow } \\
\text { production (wire ro } \\
\text { profiles, etc.) } \\
\text { - } \quad \text { wire } \\
\text { - } \quad \text { domestic } \\
\text { refrigeration equipme } \\
\text { - } \quad \text { biometallic radi } \\
\text { - } \quad \text { metal structures } \\
\text { - } \quad \text { architectural } \\
\text { products for water, ra } \\
\text { of transport (windows }\end{array}$ & $\begin{array}{l}\text { stamping } \\
\text { ler } \\
\text { uminum press-rolling } \\
\text { d, rods, pipes, foil, } \\
\text { and } \\
\text { tommercial } \\
\text { tors } \\
\text { aluminum systems, } \\
\text { ilway and other types } \\
\text { doors, portholes) }\end{array}$ & $\begin{array}{l}\text { Consumption: } \\
\text { - Engineering, private consumption } \\
\text { - Paint and varnish production } \\
\text { - Construction, engineering, furniture } \\
\text { production, food industry } \\
\text { - Trade enterprises, private consumption, } \\
\text { export } \\
\text { - Construction, private consumption, transport } \\
\text { engineering, shipbuilding }\end{array}$ \\
\hline
\end{tabular}

Figure 4 - Scheme of production and technological interrelations in the industrial cluster

Practical recommendations resulting from the research, which can be explored to improve the effectiveness of relationships with partners in the framework of the intercompany network, are aimed at the mutual development of cooperation, a clear formulation of goals and ways to achieve results. Value added as an integrator of the interests of all stakeholders should be included in the practice of managing intercompany networks.

\section{ACKNOWLEDGEMENTS}

The reported study was funded by Krasnoyarsk Regional Fund of Science according to the research project: "Determination of the development potential of high-tech industries for the deep processing of aluminum and the "Technologic Valley" for the formation of the added value of the region.

\section{REFERENCES}

[1] Katkalo V.S., Interfirm Networks: the Problems of Research in New Organizational Strategy in the 1980-1990s, St. Petersburg University Journal of Economic Studies, Russia, issue 2, pp. 21-38, 1999. 
[2] Oleynik A.N., Dominance as a result of a combination of interests: business strategies in retail and supply chains, Russian Management Journal, Russia, vol. 7/issue 3, pp. 21-44, 2009.

[3] Dementiev V. Ye., Evsyukov S. G., Ustyuzhanina Ye. V., Hybrid forms of business organization: on the analysis of inter-company interactions, Russian Management Journal, Russia, vol. 15/issue 1, pp. 89-122, 2017.

[4] Popov N.I., Tretyak O.A., Network management: new research directions, Russian Management Journal, Russia, vol. 6/issue 4, pp. 75-82, 2008.

[5] Oleskin A.V., Networks as non-hierarchical and non-market structures: implementation in biological and social systems, Economic Strategies, Russia, issue 5, pp. 2-7, 2013.

[6] Grant R., Contemporary strategy analysis: text and cases edition, 9th ed, Hoboken, NJ : John Wiley \& Sons, 2016.

[7] Shank J., Govindarajan V., Strategic cost management: the new tool for competitive advantage, New York: The Free Press, 1993.

[8] Thompson A., Strickland A., Strategic management: concepts and cases, Boston: McGrawHill Primis, 2003.

[9] Kaplinskiy R., Spreading the positive impact of globalization: an analysis of the "chains" of value increment, Voprosy Ekonomiki, Russia, issue 10, pp. 4-29, 2003.

${ }^{[10]}$ Karginova V.V., Tishkov S.V., Shcherbak A.P., Value strategy with the balance of interests: from chain to network, Tomsk State University Journal of Economics, Russia issue 29, 2017.

[11]Meshkova, T. A., Moiseichev, E. Ya., World trends in the development of global value chains and the participation of Russia in them, Finance: Theory andPractice, issue 1, pp. 83-96, 2015.

[12] Andreev P.S., Methodology for assessing the performance of Russia in the GCV and the formation of effective value chains with the participation of the APR countries 2017, RUDN Journal of Economics, Russia, vol.25/issue 1, pp. 28-40.

[13] Andreeva T.V., Designing value chains in the food industry, Vestnik of the Orenburg State University, Russia, issue 13 (132), pp. 6-13, 2011.

[14] Soldatova S.E., Volozhenko K.Yu., Identification and modeling of participation of enterprises of regional agro-industrial complex in value chains, Administrative Consulting, Russia, issue 10, pp. 83-92, 2016.

[15] OECD-WTO Trade in Value Added (TiVA): Value added in gross exports by source country and source industry, OECD Statistics, Mode of access: http://stats.oecd.org/\# 